\title{
Effect of treatment with pegvisomant on meningioma growth in vivo
}

\author{
W M Drake, A B Grossman and R K Hutson ${ }^{1}$ \\ Department of Endocrinology, St Bartholomew's Hospital, London EC1A 7BE, UK and ${ }^{1}$ Department of Radiology, University of Tennessee Medical \\ Center, 1924 Alcoa Highway, Knoxville, Tennessee 37920, USA \\ (Correspondence should be addressed to W M Drake; Email: w.m.drake@qmul.ac.uk)
}

Pegvisomant is a pegylated analogue of human growth hormone $(\mathrm{GH})$ that functions as a $\mathrm{GH}$ receptor antagonist. Although its use is currently limited to patients with acromegaly (1), there exists considerable interest in the potential use of pegvisomant for the treatment of a variety of tumours whose growth may be promoted by insulin-like growth factor-I (IGF-I). We report the case of a 74-year-old woman with acromegaly, treated with pegvisomant, in whom we have documented the growth rate of a meningioma noted incidentally during the course of routine radiological imaging.

The patient's acromegaly was diagnosed in 1992 on the basis of failure of suppression of serum GH during a $75 \mathrm{~g}$ oral glucose load (nadir serum GH $10 \mathrm{mU} / \mathrm{l}$ ) and an elevated serum IGF-I concentration $(489 \mathrm{ng} / \mathrm{ml}$, age-adjusted normal range $109-269)$. Magnetic resonance imaging (MRI) of the pituitary demonstrated a $9 \mathrm{~mm}$ intrasellar pituitary mass lesion. She declined surgical adenomectomy or pituitary irradiation and was successfully treated with thrice-daily s.c. octreotide (serum IGF-I within ageadjusted normal range). In 1998, she enrolled in a 12 week placebo-controlled study of pegvisomant in the treatment of acromegaly (2) and was randomised to receive pegvisomant $10 \mathrm{mg}$ daily. At its conclusion, she continued pegvisomant in an open-label study, but therapy was suspended after 9 months because of a shortage of drug. Eight weeks after cessation of pegvisomant, depot octreotide $10 \mathrm{mg}$ four-weekly was commenced and continued for 26 months. In December 2001, she enrolled in an open-label study of patients with acromegaly converting from stable treatment with depot octreotide to therapy with pegvisomant and continued this drug at a dose of $10 \mathrm{mg}$ daily until May 2004.

Regular surveillance pituitary imaging was performed during both clinical trials. Incidental note was made, at the start of the first trial, of a dural-based homogeneously enhancing mass related to the greater wing of the sphenoid, typical of a meningioma (Fig. 1A). She reported no symptoms referable to the mass and declined any surgical intervention. Axial, sagittal and coronal dimensions of the mass were recorded at each scan and the volume calculated, for a prolate ellipsoid, using the formula $4 / 3 \pi($ height/2) (width/2)(depth/2) (3). The volume of the meningioma increased from 470 to $4810 \mathrm{~mm}^{3} 5$ years later (Fig. 1B), with no discernible inhibitory effect of pegvisomant therapy (Fig. 2).

Pegvisomant inhibits the functional dimerisation of cell surface GH receptors, thereby reducing IGF-I

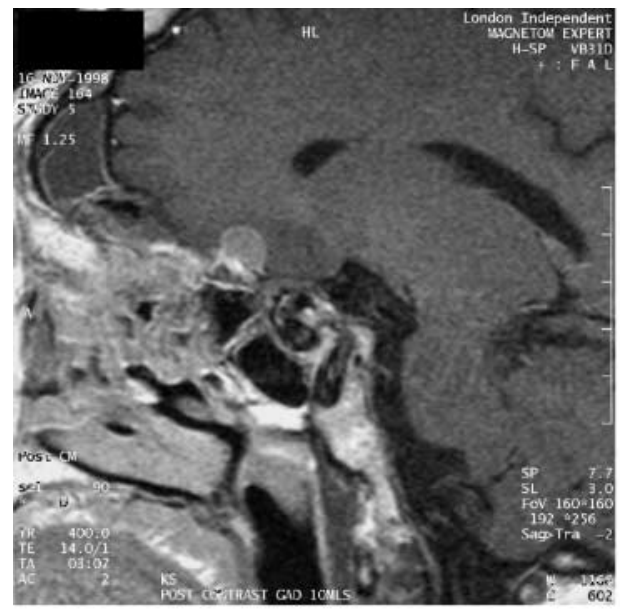

A

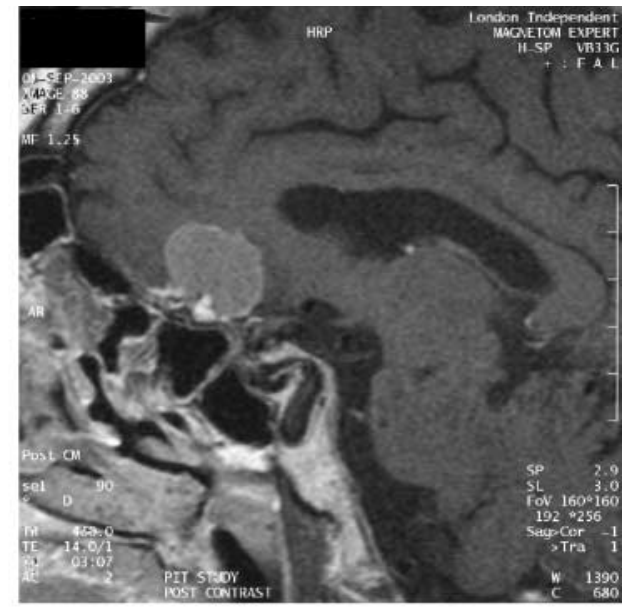

B
Figure 1 Sagittal MRI scan showing a dural-based homogeneously enhancing mass related to the greater wing of the sphenoid in 1998 (A) and 2003 (B). 


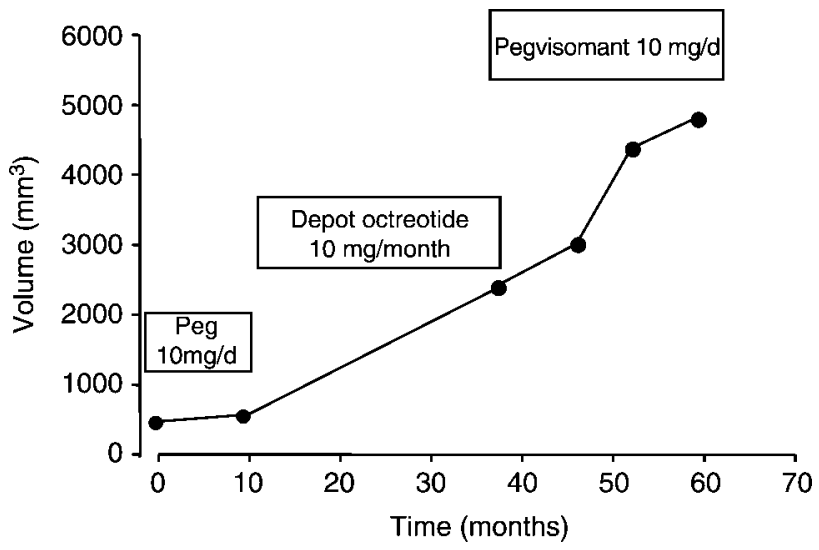

Figure 2 Meningioma volume $\left(\mathrm{mm}^{3}\right)$ vs time and the relationship to medical therapy for acromegaly.

synthesis (4). Evidence that growth of a variety of tumours is promoted by IGF-I has generated interest in the possible role of pegvisomant as an anti-cancer agent. In particular, data in nude mice indicate that pegvisomant inhibits growth of meningioma cells in vivo (5), leading to speculation that this drug may have a role in patients with inoperable or recurrent meningioma (6). To the best of our knowledge, this is the first report of the effect of pegvisomant therapy on growth of a non-pituitary tumour in vivo in a human subject. No inhibitory effect of pegvisomant therapy on meningioma growth was evident, emphasising the need for caution in extrapolating in vitro and animal data to therapy in human subjects. Further reports of the effect of pegvisomant therapy for acromegaly on coincidentally noted non-pituitary tumours are encouraged.

\section{Acknowledgements}

We gratefully acknowledge the technical assistance of Shannon K Campbell. The Department of Endocrinology receives financial support from Pfizer Inc. for its research into growth and growth factors.

\section{References}

1 Van der Lely AJ, Hutson RK, Trainer PJ, Besser GM, Barkan AL, Katznelson L, Klibanski A, Herman-Bonert V, Melmed S, Vance ML, Freda PU, Stewart PM, Friend KE, Clemmons DR, Johannsson G, Stavrou S, Cook DM, Phillips LS, Strasburger CJ, Hackett S, Zib KA, Davis RJ, Scarlett JA \& Thorner MO. Longterm treatment of acromegaly with pegvisomant, a growth hormone receptor antagonist. Lancet $20013 \mathbf{5 8} 1754-1759$.

2 Trainer PJ, Drake WM, Katznelson L, Freda PU, Herman-Bonert V, van der Lely AJ, Dimaraki EV, Stewart PM, Friend KE, Vance ML, Besser GM, Scarlett JA, Thorner MO, Parkinson C, Klibanski A, Powell JS, Barkan AL, Sheppard MC, Malsonado M, Rose DR, Clemmons DR, Johannsson G, Bengtsson BA, Stavrou S, Kleinberg DL, Cook DM, Phillips LS, Bidlingmaier M, Strasburger CJ. Hackett S, Zib K, Bennett WF \& Davis RJ. Treatment of acromegaly with the growth hormone receptor antagonist pegvisomant. New England Journal of Medicine 2000342 1171-1177.

3 Machinery's Handbook, edn 26. New York, NY: Industrial Press, Inc, 2000.

4 Kopchick JJ, Parkinson C, Stevens EC \& Trainer PJ. Growth hormone receptor antagonists: discovery, development, and use in patients with acromegaly. Endocrine Reviews 20025 623-646.

5 Friend KE. Cancer and the potential place for growth hormone receptor antagonist therapy. Growth Hormone and IGF Research 200111 (Suppl A) S121-S123.

6 McCutcheon IE, Flyvbjerg A, Hill H, Li J, Bennett WF, Scarlett JA \& Friend KE. Antitumor activity of the growth hormone receptor antagonist pegvisomant against human meningiomas in nude mice. Journal of Neurosurgery 200194 487-492.

Received 29 September 2004

Accepted 6 October 2004 